\section{Wholesale or Retail? Antoine de Marcourt's The Boke of Marchauntes and Tudor Political Theology}

\section{TORRANCE} KIRBY

Le Livre des marchans (1533) d'Antoine de Marcourt a été traduit en anglais et publié en deux différentes occasions. La première édition de langue anglaise, intitulée The Boke of Marchauntes, a été publiée par Thomas Godfray en août 1534 - année de l'adoption de l'Acte de Suprématie par le Parlement. John Fox a remarqué plus tard que ce texte avait été interdit durant la dernière période du règne de Henri VIII. La deuxième traduction, inférieure à la première et faite à partir de la deuxième édition française de 1544, a été publiée par Richard Jugge en 1547, date qui coïncide avec l'accession au trône de Édouard VI. Cet article examine les différences entre les réceptions française et anglaise de la satire de Marcourt. On y discute des diverses idées reçues au sujet de l'opposition entre le radicalisme religieux et le conservatisme politique. Cet article souligne également le patronage de Thomas Cromwell en ce qui concerne sa publication et étudie l'appel de Marcourt à la distinction entre deux théologies politiques rivales. La théologie politique du Boke of Marchauntes a définitivement un parfum bien Érastien.

Gorty years ago, in his magisterial study English Humanists and ReformaTtion Politics, James McConica observed that the English reform movement under Henry VIII and Edward VI is closely bound to the complexities of continental reform currents: "The closer the examination," claims McConica, "the more apparent is the difficulty of separating English developments from those on the Continent." Particular support for this claim can be discerned in the history of the publication in English translation of tracts by the radical French reformer Antoine de Marcourt. The first wave of French radical evangelical propaganda swept across La Manche and up the Thames estuary in the summer of 1534. On the $24^{\text {th }}$ of August an anonymous English translation of Marcourt's rollicking spoof on ecclesiastical abuses was published in London by Thomas Godfray under the title The Boke of Marchauntes. ${ }^{2}$ This was almost twelve months to the day from the publication of the original French 
text of Le Livre des marchans by Pierre de Vingle in Neuchâtel. ${ }^{3}$ Without any doubt 1534 was an altogether momentous year in the course of the Reformation for both France and England.

Just two months after the appearance of Godfray's translated editionin the so-called Affair of the Placards-Marcourt's full-frontal assault on the doctrine of the Mass precipitated a controversy which was to alter decisively (and perhaps irrevocably) the course of the Reformation in France. ${ }^{4}$ Prior to the publication of the Placards, Francis I had shown considerable favour towards les évangéliques and the reforming humanists of the groupe de Meaux; both he and his sister Marguerite of Navarre had shown marked support for Erasmus, Lefèvre d'Étaples, and Gérard Roussel and their followers, while Francis had even exiled the conservative Noël Béda to Mont-St-Michel in May of 1533. After the Placards, a veritable sea-change in the climate of religious reform can be discerned. Sharper lines of distinction emerge between the moderate humanism of the Erasmian reformers and more radical "sacramentarian" Protestants. As Francis Higman has demonstrated, two quite distinct species of religious reform were at work in France during the early 1530 s, with the complex consequence of producing in effect "two catholicisms and two protestantisms." The affair of the Placards served to highlight certain key differences among the humanists and reformers such that Marcourt's tactic, in Higman's view, should be interpreted as a deliberate attempt to subvert the moderate Erasmian reform or "réforme douce" which was progressing all too well in France at the time. ${ }^{5}$ Moreover, Marcourt's attack on the Mass and, in particular, the doctrine of the Real Presence was widely interpreted as undermining the monarchy; thus the heresy of the "luthériens" 6 as the radical evangelicals were (somewhat ironically) called, came to be identified with sedition. ${ }^{7}$ Francis turned his back on les évangéliques, and the resulting repression was sharp and swift; for many, exile or execution followed. Calvin, who had only recently been in contact with Lefèvre d'Étaples, Guillaume Briçonnet, and other moderate Erasmians in the groupe de Meaux, fled to Basel in the aftermath of the Placards and there proceeded to compose his influential Institutio christiance religionis (1536). ${ }^{8}$

In England, 1534 marked an equally highly charged turning point in the association between humanism and religious reform, although with a somewhat different result both theologically and politically as compared to what was then occurring in France. Under the talented direction of Thomas Cromwell, the Reformation Parliament had been steadily dismantling the jurisdiction of the papacy in England. As early as 1529 Jean du Bellay, French ambassador to England, interpreted the fall of Wolsey as the beginning of a concerted attack by Parliament on the independent jurisdiction of the Church. ${ }^{9}$ 
It had become evident by 1533 to ambassador Chastillon that the die had been cast; in a letter to du Bellay, now bishop of Paris, he reported that King Henry had "made up his mind to a final and complete revolt from the Holy See. [The King] says that he will have the holy word of God preached throughout the country; and our Lord, he believes, will aid him in defending his rights." ${ }^{10}$ It was in fact the labour of the parliamentary sessions of 1533-34 that saw the decisive moves against the papacy with the formal enactment of the Royal Supremacy. In strictly constitutional terms, a series of statutes beginning with the Act in Restraint of Appeals of 1533 and concluding with an Act Extinguishing the Authority of the Bishop of Rome (1536) accomplish the revolution which established Henry VIII's headship of the Church. The preamble of the former famously declares that England is an "empire," governed by one Supreme Head, namely the king, and that under his rule the Church was wholly self-sufficient "without the intermeddling of any exterior person or persons," 11 principal among them the "Bishop of Rome" as he was now officially designated. ${ }^{12}$ In November 1534, just weeks after the Day of the Placards in Paris, the Reformation Parliament broke England's ties with the jurisdiction of the Roman pontiff by declaring in the single short paragraph of the Act of Supremacy that Henry VIII was "Supreme Head of the Church of England."13 It is remarkable and indeed ironic that in England the evangelical radicalism of Marcourt's Boke of Marchauntes is enlisted in support of a royally sanctioned propaganda campaign of reform, whereas in France the same position is relegated to the extreme fringes of political subversion. What are we to make of this extreme divergence of view on opposite shores of the Channel with respect to the reception of Marcourt's text?

In her landmark study Antoine Marcourt: réformateur et pamphlétaire, Gabrielle Berthoud observes that Le Livre des Marchans is Marcourt's most popular and best-known work. ${ }^{14}$ In addition to the 1533 edition there was another, substantially revised edition in 1534, also published by Vingle in Neuchâtel followed by further editions in 1541,15 1544 (this time with Marcourt identified as the author), ${ }^{16} 1548,1555$, as well as several other editions without dates. Marcourt's work was translated into German and Dutch as well as English. ${ }^{17}$ It should also be noted here that several other works published by Vingle in the period 1533-35 also appeared in English translation. Among them were Marcourt's Petit traicté très utile, et salutaire de la Sainte Eucharistie de nostre Seigneur Jesuchrist (1534) which appeared again shortly thereafter in another edition prepared by either Pierre Viret or Vingle himself under the title Déclaration de la Messe. ${ }^{18}$ This work was published in English translation in 1547 by John Day, the same year that saw publication of the second English edition of the Boke of Marchauntes. ${ }^{19}$ In early 1534 
Vingle published a French translation of De nova et veteri doctrina (1526) by the Augsburg humanist and evangelical reformer, Urbanus Rhegius. ${ }^{20}$ Not long afterwards the same treatise was published again, on this occasion in an English translation by the eminent botanist William Turner. ${ }^{21}$ Finally, in an instance which reverses the cross-Channel evangelical influence, just weeks after the Day of the Placards Vingle published the short Traicté du Purgatoire usually attributed to Guillaume Farel, and which owes something to the English reformer and martyr John Frith's exchange on the doctrine of Purgatory with Sir Thomas More. ${ }^{22}$

The revised French edition of the Livre des marchans (1544) provided the base text for a second, though somewhat inferior English translation published by Richard Jugge in 1547, the year of the death of Henry VIII and the accession of the Edward VI. ${ }^{23}$ Referring to the first English translation of the original text of 1533, Berthoud remarks that although Godfray's Boke of Marchauntes is mentioned in the bibliographies, it remains "quasi ignoré." Berthoud then puts some questions which are well worth taking up:

On serait curieux, cependant, de connaître les motifs de son entreprise [viz. Godfray's]. Initiative personnelle? Commande d'un imprimeur, d'un groupe réformé, d'un pouvoir plus officiel? Rien ne le révèle, mais on admettra que The boke of marchauntes venait à son heure. 1534, c'est l'année de la rupture définitive du roi avec Rome, le moment où reprend la campagne contre les excès et la richesse du clergé, campagne qui aboutira, en 1540 , à la suppression totale des monastères. ${ }^{24}$

In attempting to address Berthoud's question concerning the initiative behind the translation and publication of Marcourt's satire it is well to recall certain critical circumstances of the book trade of the period. Andrew Pettegree has recently pointed out that "printers, authors, and members of the Privy Council operated within a tightly knit circle of friendship, patronage and personal connection." 25 Moreover, the close linkage of the publishing trade to the corridors of power was intrinsic to the success of Henry's revolution. Throughout England's radical constitutional transformation of the 1530s, Henry's chief minister Thomas Cromwell simultaneously managed both the intricacies of the legislative programme and a highly sophisticated propaganda campaign through the press in support of the constitutional agenda before Parliament. ${ }^{26}$ It has been argued that the substance of the pamphlets of the early 1530 s in many respects epitomizes the legislation passed by the Reformation Parliament. ${ }^{27}$ Thomas Godfray's list of published titles suggests that he was evidently an important player in Thomas Cromwell's circle. Godfray published numerous books which contributed directly to the advancement of Cromwell's propaganda campaign and was associated with some of the prin- 
cipal prophets and propagandists of the Tudor revolution, including William Tyndale, John Frith, Christopher St German, and William Marshall. ${ }^{28}$ By reviewing some of these titles, their authors and translators, we can begin to gain some intimation of the impetus for the publication of Marcourt's work and we may even be able to offer some speculation as to the possible identity of the translator.

Thomas Godfray published over 20 titles sporadically between the years 1530 and 1536. Among the titles which link him in diverse ways to the reforming interest are two important works by William Tyndale, The Obedience of a Christian Man and Pathway into the Holy Scripture, both unequivocally evangelical pieces by the great translator of the Bible. ${ }^{29}$ Tyndale's treatise on obedience draws an explicit connection between the evangelical teaching concerning justification by faith alone and the divinely derived authority possessed by the godly prince over both church and commonwealth. Richard Rex has shown that Tyndale had a serious influence on the chief propagandists of the Henrician regime especially in his demonstration of the theological ground of the Royal Supremacy. ${ }^{30}$ Rex maintains that "Tyndale's primary motive in writing Obedience was to defend the new learning against the charge that 'it causeth insurrection and teacheth people to disobey their heads and governors, and moveth them to rise against their prince'." 31 In a vein not at all dissimilar to Tyndale's, the Boke of Marchauntes launches an impassioned appeal to the secular rulers to correct the abuses of the clergy. In a clear shift of mood from the satirical to the apologetic towards the latter part of Marchauntes, Marcourt makes the case for both key theological claims, viz. the passive righteousness of faith and the royal headship of the Church.

In a direct appeal to the reformed doctrines of "grace alone" and "justification by faith," Marcourt states

\footnotetext{
Than one may see these hypocrites these... marchauntes of good works and merites: as if thei had such plenty for to sell at their pleasures. And they have given to understande/ that the frendes and benefactours of their order/ for the merits of these holy fathers have clene gotten heven/ quenching the faith/ putting in darknes/ the right holy name of Jesu/ and blasphemynge openly the grace and mercy of the lorde god/ the which is nat to be gotten bi merites or other workes or elles it shulde be no grace. ${ }^{32}$
}

In his assumed Rabelaisian identity—viz. "the lorde Pantapole, right expert in suche busynesse, nere neyghbour vnto the lorde Pantagrule"-Marcourt sets himself up as the one who sells all - celui qui "vend de tout" 33 - the wholesaler, as it were, who seeks to undercut the ecclesiastical "middleman." In this allusion Marcourt's satirical form and evangelical intent are fused together. According to the central thrust of the satire, the entrepreneurial role 
of the priestly "merchant" was that of a retailer, whose task is to distribute the spiritual "goods" of divine grace incrementally. By means of an elaborate series of steps and degrees a gradual sanctification of the faithful "consumer" was to be achieved through the mediation of a sacramental hierarchy. Over against this retail model the Lord Pantapole proposes that these goods are available "wholesale," that is to say in the universal form Luther famously identified as a "total" or justifying righteousness, communicated by wholly sufficient authority of scripture (sola scriptura) to the individual believer by grace alone (sola gratia) by means of faith alone (sola fide) without the necessary mediation of tradition, the merit of good works, and the elaborate sacramental apparatus of an ecclesiastical "retailer." 34

In another passage adjacent to this treatment of the mode of the distribution of grace Marcourt urges that the care of religion be taken under the direct control of the civil power:

\begin{abstract}
What you noble and virtuous princes/ lordes/ and ladyes: why do ye nat loke on these marchauntes? And yet/ nat withstanding /that by pride/ they will nat be visited: yet have you/ whether thei wyll or not/ auctorite over them/ and unto you/ it apperttaineth to chastise/ to correcte/ and to put downe/ the great excesse of such [Cii $\left.\mathrm{r}^{\circ}\right]$ theves. Than do it/ that the sayenge of Esaie be nat verified and fal upon you (Esa. [Isaiah] i) Thy princes be unfaithfull/ felowes unto theves. But rather that in the presence of the lyvinge god/ whose name ye bere; Who hathe given you the power of the swerde/ for to use unto his honour/ defending the innocents/ punnisshinge all evyll doers/ ye may be found faithfull and trewe/ consenting unto all goodnesse/ resisting unto the evyll with all your might for his good wyl/ for unto this ar you committed by him/ that he onely may exalte you or put you downe/ in the lyfe present and to come: and of this be acertened/ that if you go about for to honour him/ he wyll honour you/ if you exalte him/ he shall exalte you. [Cii $\mathrm{v}^{\circ}$ ] By his wisedom/ the kynges rayne and the lordes governe/ and ordayne holy thinges. ${ }^{35}$
\end{abstract}

In the midst of Marcourt's blistering satire of the sacramental apparatus of the Church hierarchical we are suddenly confronted with the proposition that by no means are authority and hierarchy per se the source of spiritual abuses. Rather, Marcourt explicitly invites "virtuous princes" to be the "visitors" of the clergy, that is "to chastice/ to correcte/ and to put downe/ the great excesse" of the ecclesiastical "marchauntes." God has given princes the "power of the sword" and therefore, according to an argument made famous by Marsilius of Padua, princes hold jurisdiction over the church. The passage concludes with a quotation from the Book of Proverbs which became a classic scriptural locus cited by Tudor defenders of the Royal Supremacy, and in Tyndale's translation reads "By me [i.e. by the divine Wisdom] kings reign, and princes decree justice; by me princes rule, and nobles, even all the judges of the earth." 36 Marcourt's claim, made equally by Tyndale, Luther, 
and Zwingli, is that the authority of princes is not mediated by the Church and her hierarchs, but is rather an un-mediated divine gift.

Here, I believe, we are approaching the matter of Marcourt's sustained satire of merchants and merchandise. The merchant is by definition "one who deals in goods not manufactured or produced by himself" and in early usage the name of merchant is restricted to those who have dealings with foreign lands. 37 "For truly it is nedefull/ that the abundaunce of one contrey/ supplye and satisfye unto that/ whiche nedeth in another." 38 The two countries between which this trade occurs would be plain to any contemporary reader conversant with Paul's epistles as none other than the heavenly and the earthly cities. By Marcourt's account

Laborious/ diligent/ and industrious persons be requisite/ for the entertaining of the publyke welth/ the which with out finesse/ fraude/ or subtlety to have the distributynge/ and haunting/ to change/ conserve and transporte many sortes of marchandyses/ from one place to another according unto the convenience of tymes/ and the necessyte of the people. Unto the whiche the trewe marchauntes is right lefull/ as unto good and faithfull servauntes of the commune welth... 39

However, as Marcourt continues in this same introductory passage,

This estate/ wheof I speke/ as honourable/ as it is in the temporal and civyll welth/so accursed and detestable it is in the divine and spirytuall lyfe: And for all that god hath permitted in his furour/ that in steed of good herdmen/ and trewe ministers of his holye worde/ that ther shulde come/ I do nat say alonly gret marchauntes/ but furiouse theves/ and insaciable ravening wolves. ${ }^{40}$

The primary questions addressed in this satire concern both the cure of souls and the ultimate derivation of jurisdiction and power in human political community. Indeed, viewed through the satirical lens of "the estate of merchauntes" these two questions can perhaps be viewed as one and the same question, namely a fundamental question concerning the manner of the mediation of certain primary "goods" - whether these goods be the divine gifts of grace and salvation to the individual believer or the divine gift of rule to the leaders of the human community. According to the radically evangelical position staked out by Marcourt - and in this he is in essential agreement with such evangelical reformers on the continent as Guillaume Farel, Pierre Viret, Huldrych Zwingli, and Jean Calvin, or William Tyndale, John Frith, William Turner, and Clement Armstrong in England-both individual salvation and supreme political power are "merchandise" properly transmitted from one country to another, as it were from heaven to earth, from the spiritual realm to the temporal realm, without the necessity of mediation by an entrepreneurial 
(in the literal sense of this term) ecclesiastical hierarchy. Why, then, is the "estate of merchauntes" honourable in the "temporal and civyll welth" and yet "accursed and destable in the divine and spirytuall lyfe"?

What we have in the Boke of Marchauntes is a thorough affirmation of the Augustinian dialectic of the two cities where the key consideration is to avoid the mixing or confusion of things spiritual with things temporal. Perhaps the most famous formulation of this Augustinian position in the sixteenth century is by another French reformer, Jean Calvin, who states the position in this way:

In man government is twofold: the one spiritual, by which the conscience is trained to piety and divine worship; the other civil, by which the individual is instructed in those duties which, as men and citizens, we are bold to perform. To these two forms are commonly given the not inappropriate names of spiritual and temporal jurisdiction, intimating that the former species has reference to the life of the soul, while the latter relates to matters of the present life, not only to food and clothing, but to the enacting of laws which require a man to live among his fellows purely honourably, and modestly. The former has its seat within the soul, the latter only regulates the external conduct. We may call the one the spiritual, the other the civil kingdom. Now, these two, as we have divided them, are always to be viewed apart from each other. When the one is considered, we should call off our minds, and not allow them to think of the other. For there exists in man a kind of two worlds, over which different kings and different laws can preside. By attending to this distinction, we will not erroneously transfer the doctrine of the gospel concerning spiritual liberty to civil order, as if in regard to external government Christians were less subject to human laws, because their consciences are unbound before God, as if they were exempted from all carnal service, because in regard to the Spirit they are free. ${ }^{41}$

Under attack in the satire of the Boke of Marchaunts is the competing "retail" logic of the lex divinitatis, famously formulated by Boniface VIII in the bull Unam Sanctam, where the case in favour of the merchants is most eloquently stated. With the able assistance of the learned canon lawyer Giles of Rome, Boniface summarizes the merchandizing logic of medieval spirituality which is so thoroughly at odds with the high Augustinian position maintained by Marcourt and Calvin. In formulating the theological principle of priestly, sacramental function, Boniface invokes the so-called lex divinitatis, the fundamental "law of divinity" as declared by the great sixth-century Syrian Neoplatonist, Pseudo-Dionysius the Areopagite. ${ }^{42}$ In the bull Unam Sanctam Boniface defends the doctrine of the papal plenitude of power (plenitudo potestatis) by asserting the necessary hierarchical subordination of temporal to spiritual jurisdiction: 
For according to the Blessed Dionysius, it is the law of divinity (lex divinitatis) that the lowest things are led to the highest by intermediaries. Then, according to the order of the universe, all things are not led back equally and immediately, but the lowest by the intermediary, and the inferior by the superior... Therefore if the terrestrial power err, it will be judged by the spiritual power. ${ }^{43}$

This relation of subordination between the spiritual and the temporal realms establishes the ecclesiastical hierarch as an ordained agent or sacramental mediator between the worlds. It is precisely this notion of a priestly mediation between the two realms which constitutes Marcourt's spiritual "estate of marchaundyse" 44 and thus serves as the principal target of his evangelical satire throughout the Boke of Marchauntes.

From Marcourt's Augustinian standpoint the mercantile principle of the merely "external" mediation of goods between one temporal realm and another of the same order "for the tyme of this present lyf" is "worthy prayse and righte utyle." 45 Yet any attempt "to change/ conserve and transporte many sortes of marchandyses" from the realm of the divine and spiritual life into the realm of temporal and civil life is "accursed and detestable." Such trade is not the work of "good herdmen/ and trewe ministers of [God's] holye worde" but of "furiouse theves/ and insaciable ravening wolves." The very attempt to act as an intermediary between the realms is in the nature of a deception, namely "to sell the thinge that is nat his" to sell; it is to confuse the substance of one order of reality with another after the example of the Alchemist:

The gret Lycyfere/ I wolde say the gret lorde of these marchauntes/ which is the sleyghtest of all / holdeth his banke open unto all folks/ convertynge the leade unto golde. There was never such multiplying by Alkemyst seen in this worlde/ as he and his doth fynde/ to fynde suche a vayne of golde under lead. ${ }^{46}$

There is a curious resonance between this satirical depiction of merchandizing alchemy by Marcourt and Chaucer's "Canon's Yeoman's Tale" in the Canterbury Tales, interestingly also one of the 20 or so books published by Thomas Godfray in the early 1530s. ${ }^{47}$ Chaucer's Pardoner- "I preche of no thing but for coveityse./ Therefore my theme is yet, and evere was,/ Radix malorum est cupiditas"- is the very personification of Marcourt's entrepreneurial cleric. ${ }^{48}$ As was the Boke of Marchauntes the Canterbury Tales were also published cum privilegio regali, with royal sanction. Given the sharpness of Chaucer's critique of the vagaries and abuses of the late-medieval Church, it is arguable that the republication of Canterbury Tales might itself be considered a contribution to the campaign of propaganda orchestrated by Thomas Cromwell to coincide with the revolutionary doings of Parliament at this time. 
Also published by Godfray was a translation of Lorenzo Valla's debunking of the so-called "Donation of Constantine," the eighth-century forgery which lent support to papal claims to the plenitudo potestatis or sovereign power to the detriment of the temporal power. ${ }^{49}$ Here too we see the same theme emerge: the promotion of a redefinition of spiritual power away from the hierarchical claims of the papacy implicit in the lex divinitatis and towards the totalizing claim of the temporal power over all matters of external jurisdiction. The translator of Valla's treatise was none other than William Marshall, who also translated, "with the kynges moste gracyous priuilege," that great late-medieval work of Augustinian political theology, Marsilius of Padua's Defender of the Peace. ${ }^{50}$ Marshall, a not implausible candidate for translator of the Boke of Marchaunts, was among the most assiduous of Cromwell's circle in his defence of the Royal Supremacy. ${ }^{51}$ Although official sponsorship of all the books published by Thomas Godfray and others in the propaganda campaign of 1533 through 1536 cannot be proven, there is evidence of a direct subsidy for Marshall's translation of Defensor Pacis. ${ }^{52}$ The relevance of this fourteenth-century work of Augustinian political theology to the Tudor revolution is evident in Marsilius's chief aim, namely to expose the Roman Papacy's quest for domination - the libido dominandi definitive of Augustine's civitas terrena - that is, not only of the spiritual sphere but of the temporal or civil realm as well. ${ }^{53}$ According to Marsilius this overreaching of spiritual authority was the central cause of conflict and disorder within Christendom. ${ }^{54}$ The critique of the jurisdictional claims of the papacy in Defensor Pacis can be fairly characterized as resting upon a rejection of what was perceived as the "mercantile" logic of the lex divinitatis articulated by Boniface and Giles of Rome in favour of Augustine's "two cities" model. Once again we can discern the very appropriate fit of Marcourt's satire within the larger scheme of the literary campaign mounted by Thomas Cromwell in support of Henry VIII's constitutional revolution.

Thomas Godfray also published Marshall's translation of Martin Bucer's iconoclastic treatise Das Einigerlei Bild: "pyctures [and] other ymages which were wont to be worshypped, ar i[n] no wise to be suffred in the temples or churches of Christen men." ${ }^{55}$ As in the satire of the Boke of Marchauntes, the question addressed by Bucer is ultimately concerned with the pivotal question of "mediation." The evangelical profession of the sufficiency of scripture to salvation - sola scriptura - leads to the rejection of images, relics, and the like in favour of a direct access to the divine message through the Word. In a summary of this reforming position, Lefèvre d'Étaples states that 
The Word of God alone suffices. This alone is enough to effect life everlasting. This rule is the guide to eternal life. All else, on which the Word of God does not shine, is as unnecessary as it is undoubtedly superfluous. Nor should such be reckoned with the Gospel as far as the purity of the pious worship and the integrity of faith are concerned, for it is not the creation of God. ${ }^{56}$

Marcourt frames the question consistently with the satirical conceit of the merchants' estate: "is it nat a gret sleyghtnesse [habilité] for to sell well and in sellynge/ to be well payde/ and that the byer finally shal have nothing but the sight?"57

Common lawyer and political theorist Christopher St German was another key player in Cromwell's circle of religious and constitutional reformers. His sustained literary attack on the papacy resulted in a series of pamphlets with an increasingly sharp edge. While several of St German's contributions to the propaganda campaign were published by the King's own printer, Thomas Berthelet, ${ }^{58}$ one of the common lawyer's more strident pieces, $A n$ Answer to a Letter, was published by none other than Thomas Godfray. ${ }^{59}$ In An Answer St German sets out to redefine the nature of the Church in a manner consistent with the King's claim to the plenitudo potestatis. Not only do kings exercise the "cure of souls" but they are also the final arbiters of both doctrine and the interpretation of the scriptures:

let every man therefore iuge whether any curate may truly say: the kyng hat only cure of the bodyes of my parysshens, but I of their soules: for it is no dout but that kynges and princes have cure and charge over both, and that nat only over the soules of laye men: but also of the soules of bysshops and prestes...

... for as moche as the unyversall catholique people can nat be gathered togyther to make suche exposycion [of the scripture], therefore it semeth that kynges and princes whom the people have chosen and greed to be their rulers and governours, and which have the whole voices of the people, may with theire counsel spirytuall and temporall make exposycyon of such scripture as is doutfull so as they shall thynke to be the true understanding of it, and none but they, and that theire subiectes be bounden even by the law of god to folowe their exposycion... ${ }^{60}$

Without any doubt Antoine de Marcourt is in step with St German and other leading Tudor propagandists of the Royal Supremacy in his appeal to the model of the virtuous Old Testament kings whose care was for both the honour of God and the good governance of the people:

Dispisyng of the divine wyll and wysedom is cause of all evils/ on kinges/ princes/ lordes/ contreis and nations/ which hath ben sene by David Salomon/Ezechie/ Achab/ Manasses/ and other lyke. And one ought nat to have fere for to avaunce the honoure of god/ as poore simple Sedechie had/ feryng more the princes of Juda and Hierusalem 
than the only god/ nat believing the counsel of good Hieremie... For it is nat in the power of men/ to depreve kynges of their crownes: but only appertayneth unto god/ which tranposeth the kingdoms as it plesith him... ${ }^{61}$

In the parallel case of Clement Armstrong, another radical evangelical in the circle of Thomas Cromwell, Ethan Shagan has shown with wonderful clarity that religious radicalism is by no means necessarily opposed to authoritarian political theology. ${ }^{62}$ Armstrong, sacramentarian opponent of the Masscertainly a radical position to hold in the 1530 s - nonetheless defined the Church as "the congregation of all men in a realm congregated as in the body of one man, which one man is the king's body wherein all people his subjects are as his bodily members... like as the king is the Church, so the Church is the king." 63 That Marcourt's satire could be in basic accord with Tyndale, St German, Martin Bucer, and Marsilius of Padua on key questions of religious and political reform challenges certain historiographical assumptions about the Reformation. In the case of Clement Armstrong, Shagan has shown how Henry VIII's anti-papal manoeuvres of the early 1530s were received and embraced by London's radical Protestant community. Far from eroding the authority of Princes, the assertion of a radical evangelical agenda could go hand in hand with a revolutionary extension of royal powers. For Marcourt as for Armstrong and others in the circle of Thomas Cromwell, the Royal Supremacy is held to be consistent with radical doctrinal reform.

In considering the variety yet underlying common cause of books published by Thomas Godfray in the period 1533-36, the appearance among them of the anti-clerical satire of a radical evangelical of Marcourt's stripe appears wholly in keeping with the constitutional aims of the royally sanctioned literary campaign, if not entirely consistent with other doctrinal policies of the realm. While Marcourt is also associated with theological radicalism - and his Articles veritables published as the Placard of October 1534 confirm his radical Sacramentarian leaning which, like Armstrong's, could not have been reconciled with the position on the Mass and the real presence countenanced by King Henry - it is nonetheless plain that the Boke of Marchauntes lends solid support to the new ideology of kingship unfolding in the agenda of the Reformation Parliament and its accompanying propaganda. That Cromwell formally sanctioned publication of the satire is externally confirmed by Godfray's colophon "cum privilegio." More to the point, however, is the demonstrable consistency of the Boke of Marchauntes with other leading contributions by Godfray's press to the government's literary campaign. This openly official approval of Marcourt's book contrasts sharply with the attempt at concealment of the publisher's identity and the place of publication in Pierre de Vingle's French editions of 1533 and $1534 .{ }^{64}$ One important piece of evi- 
dence of this marked discrepancy in the official reception of Marcourt's satire on the two sides of the Channel is discernible in a slight but revealing rhetorical modification in the use of the personal pronoun. In the peroration of the appeal to the Princes in the original Vingle edition of 1533, Marcourt writes "O, si ainsi promptz et vigilans vous estiez à procurer l'honneur de Dieu comme sont promptz et diligentz ces convoiteux marchans de estre apres leur cas pour bien garder que rien ne leur eschappe, las que la chose iroit bien." 65 The rhetorical effect is admonitory, perhaps even reproving. In the English translation of Godfray's 1534 edition, the pronoun shifts from second person to first: "O lorde/ if we were so prompt and wakinge for to procure the honour of god/ as these covetouse marchantes be prompte and diligent/ for to be about theyr maters/ and to be well ware that nothinge escape theym: Helas all wolde goo well." 66 The shift of discourse from second-person to first-person-from "you" to "we"- suggests some degree of complicity or common purpose between author and the intended hearer of the apology, namely the godly Prince. This subtle discrepancy in translation points to a world of difference between the official reception of Marcourt's pamphlet in England as compared with France.

The identity of the translator of Marcourt's satire remains an enigma. One possibility is William Marshall for whom Godfray printed several translations, although all of those positively identified are either from Latin or German. ${ }^{67}$ Another possible candidate for translator is William Turner, translator of Rhegius's The old learninge and the newe (1537), previously published in Neuchâtel by Vingle in 1534 as La Doctrine nouvelle et ancienne. Had he not died in 1531, Simon Fish might have been another possibility, for he has been credited with the translation of continental evangelical tracts from French into English. ${ }^{68}$ Even Christopher St German cannot be ruled out since he is numbered among Thomas Godfray's translators of humanist and reformist literature. ${ }^{69}$ Much less likely is Thomas Starkey, another humanist in the circle of Thomas Cromwell, although there is the circumstantial evidence that he had been studying law in Avignon from 1532 before his return to England around the time of the publication of the Boke of Marchauntes. Another thoroughly unlikely candidate is Giles du Wes (alias du Guez), French tutor to the Lady Mary (afterwards Queen Mary) and librarian to Henry VIII, even though he was the author of a two-volume French grammar published by Godfray in $1534 .{ }^{70}$

A generation later, in Actes and Monuments, John Foxe ${ }^{71}$ mentions the Boke of Marchauntes as having been included in a list of books prohibited by Henry VIII in a Proclamation issued in 1546, two years after the theology faculty of Paris had issued France's first index of prohibited books. ${ }^{72}$ 
Accompanied by a host of other evangelical writings by such reformers as Miles Coverdale, George Joye, William Tyndale, John Frith, William Turner, and Robert Barnes, The Boke of Marchauntes was consigned to a bonfire at Paul's Cross. ${ }^{73}$ The list divides up the books into order according to author and includes The Boke of Marchauntes within a subsection of titles attributed to William Turner including The huntyng \& fyndyng out of the Romishe fox and A comparison betwene the olde learnynge and the newe. This may well be the strongest clue as to the identity of the translator, although perhaps not altogether convincing. It is interesting to note that the item immediately preceding The Boke of Marchauntes in the list of prohibited books attached to the Royal Injunction is The Summe of the holye Scripture, ${ }^{74}$ an English translation of Summa der godeliker Scrifturen, originally a work in Dutch which appeared in Leyden in 1523 and attributed to Henricus Bomelius (or Hendrik von Bommel), an evangelical preacher in the region of the Lower Rhine and Pastor of the Brethren of the Common Life. ${ }^{75}$ The English translation is attributed to another evangelical firebrand, Simon Fish, author of the popular evangelical satire Supplicacyon for the beggars, first circulated in the spring of 1529 and a copy of which Anne Boleyn is said to have presented to Henry VIII. ${ }^{76}$ Both Simon Fish and John Frith were engaged in polemics with Sir Thomas More concerning the doctrine of purgatory, and thus serve to highlight the developing rift between Erasmian humanist and radical evangelical approaches to religious reform. Moreover, as Isabelle Crevier-Denommé has shown, the French translation of this text-Summe de l'escripture saincteprovides yet another instance of links between England and the press of Marcourt's publisher in Neuchâtel, Pierre de Vingle. ${ }^{77}$ Yet again we witness the impossibility of separating developments in the course of the Reformation in England from events on the continent.

James McConica's claim in English Humanists and Reformation Politics that the humanist evangelicals of Henry's reign "declined the general heterodoxy of the Protestant reformers" and embraced the middle way of Erasmian moderation as "the very formula of the Henrician Church" does seem now a rather unlikely reading of the polemical environment which witnessed the officially sanctioned publication of Marcourt's satire. ${ }^{78}$ Thomas Godfray's press played a key role in Cromwell's anti-papal campaign from 1533 through 1536, and the Boke of Marchaunts was one among numerous tracts by evangelical radicals published in support of the Royal Supremacy. Francis Higman's suggestion that there is a duality in both the Protestantism and the Catholicism of the 1530s is helpful. England's reformist humanism had its "evangelical moment" in the 1530 s and then reverted to a more consciously conservative mode in the decade following. From the fall of Thomas 
Cromwell in 1540 until the death of Henry VIII in January 1547, the Church of England came to be dominated by the spirit of a conservative Erasmian humanism such as it had known prior to $1533 ;{ }^{79}$ during the same period of the middle 1540s France witnessed a severe repression of heresy and rigorous enforcement of Catholic orthodoxy. ${ }^{80}$ With the accession of Edward VI, "the young Josiah," the climate shifted once again. Phoenix-like, The Boke of Marchauntes was resurrected in its second English edition just months after perishing in the flames at Paul's Cross. Within a year, continental evangelical theologians Martin Bucer from Strasbourg and the Florentine Peter Martyr Vermigli would be installed in Cambridge and Oxford respectively as the King's Professors of Divinity. Those in France who longed for a ruler who would emulate the idol-smashing boy-king of Ancient Judah would have to wait until the accession of Francis II in 1559 and then Charles IX in 1560, only to have their hopes of a thorough reform of church and doctrine dashed in the wake of the Colloquy of Poissy (1561). ${ }^{81}$ The tide of religious reform was far from attaining equilibrium on either side of the Channel.

\section{Faculty of Religious Studies, McGill University}

\section{Notes}

1. James Kelsey McConica, English Humanists and Reformation Politics under Henry VIII and Edward VI (Oxford: Oxford University Press, 1965), p. 6.

2. The Boke of Marchauntes, right necessarye vnto all folkes. Newly made by the lorde Pantapole, right expert in suche busynesse, nere neyghbour vnto the lorde Pantagrule (printed at London by Thomas Godfraye, cum priuilegio Regali, 1534).

3. The original text was published by Vingle on 22 August 1533 under the title Le Livre des marchans, fort utile a toutes gens nouvellement composé par le sire Pantapole, bien expert en tel affaire, prochain voysin du seigneur Pantagruel. See Gabrielle Berthoud, Antoine Marcourt: Réformateur et Pamphlétaire du "Livre des Marchans» aux Placards de 1534 (Genève : Droz, 1973). Berthoud writes: "le Livre des Marchans est l'œuvre la plus populaire et, apparemment, la mieux connue de l'auteur des Placards." (p. 111)

4. The placard was formally titled Articles veritables sur les horribles, grandz et importables abuz de la Messe papalle, inventee directement contre la saincte Cene de Jesus Christ, and was printed by Pierre de Vingle: Neuchâtel, 10 October 1534. Marcourt's sharp polemic against the Catholic doctrine of the Mass was posted throughout Paris as well as at the château of Amboise where Francis I was residing. See Francis Higman, "De l'affaire des Placards aux nicodémites : le movement évangélique français sous François Ier," Lire et découvrir : la circulation des idées au temps de la Réforme (Genève: Droz, 1998), pp. 619-25.

5. Francis Higman, Lire et découvrir, pp. 622, 623. According to David Nicholls, "Looking for the origins of the French Reformation," Power, Culture, and Religion in France, c. 1350 - 1550, ed. Christopher Allmand (Woodbridge, UK: Boydell, 1989), p. 141: "Humanism did not lead inexorably to Protestantism, but humanist reforms continued alongside the new religion until the outbreak of civil war imposed often unpalatable 
choices. The concern for the right ordering of religion could not now be separated from doctrinal matters..."

6. "In the eyes of the Sorbonne doctors, all of those involved in activities such as the Meaux experiments constituted what the Sorbonniste Noël Béda called 'Luther's confraternity'." Philip Benedict and Virginia Reinburg, "Religion and the Sacred," in Mark Holt, ed., Renaissance and Reformation France, 1500-1648 (Oxford: Oxford University Press, 2002), pp. 136-7. It was ironic that the radicals were called "luthériens" since Marcourt's Articles veritables reveal that he and others among his supporters "had gone beyond Lutheran ideas and [Erasmian humanist] anti-clericalism to adopt the more radical doctrine of the Swiss Protestants," notably by their embrace of Huldrych Zwingli's denial of the real presence of Christ in the eucharistic elements. See Frederic J. Baumgartner, France in the sixteenth century (New York: St Martin's Press, 1995), pp. 137-40.

7. See Christopher Elwood, The Body Broken: the Calvinist doctrine of the Eucharist and the symbolization of power in sixteenth-century France (New York: Oxford University Press, 1999), pp. 27-55. Donald R. Kelley, The beginning of ideology: consciousness and society in the French Reformation (Cambridge: Cambridge University Press, 1981), pp. 13-9, argues that the Placards episode transformed French Protestantism in the minds of many contemporaries into a clearly defined "religion of rebels" which had to be stamped out.

8. See Benedict and Reinburg, pp. 138, 139.

9. Letters and Papers, Foreign and domestic of the reign of Henry VIII, 1509-1547, ed. J.S. Brewer, J. Gairdner, and R.H. Brodie, 22 volumes (London: Longmans, 1862-1932), iv (3), 6011: 17 October 1529. Cited by McConica, p. 108.

10. Chastillon's letter of 17 November 1533 is cited in William Thomas, The Pilgrim: a dialogue on the life and actions of King Henry the Eighth, ed. J.A. Froude (London: Parker and Bourne, 1861), p. 99. See Richard Rex, "Crisis of Obedience: God's Word and Henry's Reformation," The Historical Journal 39.4 (1996), p. 889.

11. 24 Henry VIII, c. 12. This Act prevented legal appeals from English ecclesiastical courts to Rome as final arbiter, and thus solved the difficulty of potential appeals against his divorce of Catherine of Aragon. See Richard Rex, Henry VIII and the English Reformation (Basingstoke: MacMillan, 1993).

12. For discussion of the progression of the revolutionary legislative agenda of the Reformation Parliament see Rex, "The Crisis of Obedience," p. 879 ff.

13. 26 Henry VIII, cap. 1:

Albeit, the King's Majesty justly and rightfully is and oweth to be the supreme head of the Church of England, and so is recognised by the clergy of this realm in their Convocations; yet nevertheless for corroboration and confirmation thereof, and for increase of virtue in Christ's religion within this realm of England, and to repress and extirp all errors, heresies and other enormities and abuses heretofore used in the same, Be it enacted by authority of this present Parliament that the King our sovereign lord, his heirs and successors kings of this realm, shall be taken, accepted and reputed the only supreme head in earth of the Church of England.

14. Berthoud, pp. 111 and $149 \mathrm{ff}$. 
15. Le liure des marchans. Reueu \& augmente par sont [sic] premier autheur (Genève: [Jean Michel], 1541). See Berthoud, p. 127.

16. Le Livre des marchans... Nouvellement revue et augmenté, par son premier autheur $M$. Anthoine Marcourt, bien cognoissant telles affaires (?1544). This is the only edition known to carry the name of the author. See Berthoud, p. 128.

17. Berthoud, p. 140.

18. The second edition of Marcourt's Petit traicté de la Saincte Eucharistie was issued under the pseudonym Cephas Geranius with the altered title Declaration de la messe : le fruict dicelle, la cause et le moyen pourquoy \& comment on la doibt maintenir (Neuchâtel : Pierre de Vingle, 1534). See Berthoud, pp. 244-51.

19. A declaration of the masse, the fruite thereof, the cause and the meane, wherfore and howe it ought to be maynteyned. Newly perused and augmented by the first author therof. Maister Anthony Marcort at Geneue. Tra[n]slated newly out of French into English (Wittenberge [i.e. London]: H. Luft [i.e. John Day], 1547).

20. La Doctrine nouvelle et ancienne (Neuchâtel : Pierre de Vingle, 1534?). On the translation see the as yet unpublished essay by Isabelle Crevier-Denommé and William Kemp, "La traduction et l'adaptation de la doctrine nouvelle et ancienne de Rhegius (Genève, 1542-4, Neuchâtel vers 1534)," Cinq siècles d'histoire religieuse Neuchâteloise ; approches d'un tradition Protestante, delivered at the l'Institut d'Histoire de Neuchâtel in 2005.

21. A co[m]parison betwene the olde learnynge [and] the newe, translated out of latin in Englysh by Wyliam Turner (Southwarke: James Nicolson, 1537). As were both of Marcourt's tracts-The Boke of Marchauntes and A declaration of the masse-Turner's translation was republished after the accession of Edward VI. See The old learnyng and the new, compared together. Newly corrected and augmented by W. Turner (London: R. Stoughton, 1548). Turner's most famous contribution to the literature of religious reform was The huntyng \& fyndyng out of the Romishe fox (Basle [in actuality Bonn: L. Mylius], 1543).

22. [Guillaume Farel], Sumaire \& briefuve declaration d'aucuns lieux fort necessaires a ung chascun chrestien pour mettre sa costace en Dieu et ayder son prochain; Item ung Traicte du purgatoire, nounelle met adiouste sur la fin ([Neuchâtel : Pierre de Vingle], 1534). John Frith, A disputacio[n] of purgatorye made by Iohan Frith which is deuided in to thre bokes (Antwerp: S. Cock, 1531).

23. The Booke of Marchauntes, very profitable to all folks... (London: Jugge, 1547) was one of Jugge's first publications. Jugge was appointed to the office of Queen's Printer in 1560, months after the accession of Elizabeth I. For a discussion of the differences between this text and the first English edition by Godfray as well as divergences of both English editions from the French editions upon which each is based, see Berthoud, pp. 142-6.

24. Berthoud, p. 142.

25. Andrew Pettegree, "Printing and the Reformation: the English Exception," in Peter Marshall and Alex Ryrie, eds, The Beginnings of English Protestantism (Cambridge: Cambridge University Press, 2002), p. 173. See also Diarmaid MacCulloch, Thomas Cranmer: A Life (New Haven: Yale University Press, 1996). 
26. G. R. Elton, Reform and Reformation: England 1509-1558 (Cambridge, Mass.: Harvard, 1977), p. 157: "Cromwell obtained a grip on the press in the latter part of 1533. Under his patronage a very different body of writers and writings took over the task of discussing the issues of the day; production turned from controversy to constructive thought."

27. According to Franklin Le Van Baumer, Henry VIII and Cromwell devoted almost as much attention to the printing press as to the parliamentary session. See The Early Tudor Theory of Kingship (New York: Russell and Russell, 1966), pp. 35-84. On p. 39 he writes: "Henry VIII exercised a dictatorship of the press which, judged by its results, was just about as effective as any western Europe has ever seen. The opposition, denied the use of the English printing press, was either driven abroad to publish, or else forced to circulate its views in manuscript."

28. Also an unattributed "panegyric of King Henry VIII as the abolisher of papist abuses" (1536?) is identified in the Short Title Catalogue (2nd ed.) 13089a as published by Thomas Godfray, Bodleian Library, Douce Fragm. f.51 (10).

29. William Tyndale, The obedyence of a Chrysten man: and howe Chrysten rulers ought to gouerne, wherin also (yf thou marke dilygently) thou shalte fynde eyes to perceyue the craftye conueyaunce of all iugglers (London: Thomas Godfray?, 1536); A Pathway i[n] to the Holy Scripture (London: Godfray, 1536?) and a modern edition of the latter ed. P.E. Satterthwaite and D.F. Wright (Grand Rapids, MI: Eerdmans, 1994).

30. Rex, "Crisis of Obedience," pp. 863-7.

31. Rex, "Crisis of Obedience," p. 866.

32. Boke of Marchauntes, $\mathrm{Cv} \mathrm{r}^{\circ}$. See also $\mathrm{Av} \mathrm{v}^{\circ}$ : "These avaricyouse marchauntes covetouse of glory/ paynt their workes/ attributing unto them selves/ that/ which apptayneth unto the onely god: as iustice/ virtue/ wysedom/ pardon/ mercy/ remission of synne."

33. See Berthoud, p. 111. Berthoud, however, does not provide the precise Greek etymology of this Rabelaisian name. The Greek $\pi \alpha{ }^{2} \nu \tau \alpha$ (panta) is "all" and $\pi \omega \dot{\lambda} \eta \varsigma$ (poles) is "dealer," "seller," or "purveyor." According to Anne Lake Prescott, Marcourt's assumed identity is the first printed allusion to Rabelais in English. See Prescott, Imagining Rabelais in Renaissance England (New Haven and London: Yale University Press, 1998), p. 17.

34. See, for example, Luther's Wittenberg lectures of 1531 on Galatians, In epistolam Sancti Pauli ad Galatas commentarius (Wittenberg: G. Rörer, 1535); Martin Luther, Werke Weimarer Ausgabe (WA) 40 I. The first English translation appeared in 1575, A commentarie of M. Doctor Martin Lvther vpon the Epistle of S. Paul to the Galathians, first collected ... out of his preaching, and novv out of Latine faithfully translated into English ... (London: Thomas Vautroullier, 1575).

35. Boke of Marchauntes (London: Thomas Godfray, 1534) $\mathrm{Ci} \mathrm{v}^{\circ}$. See the Vingle edition of Livre des Marchans (1533), Bviii $\mathrm{r}^{\circ}$ :

Que faictes vous, nobles et vertueux princes, seigneurs et dames, que n'avez vous sur ces marchans icy regard? Et non obstant que par orgueil ilz ne veullent pas estre visitez si avez vous, veulent ou non, sur eulx autorité, et a vous appartient de chastier, de corriger et reprimer les grans exces de telz larrons; faictes le donc, affin qu'il n'adviengne que de vous soit verifié ce que dict Esaie. Telz princes sont infideles, compaignons des larrons. Mais plus tost que en la pre- [Bviii $\left.\mathrm{v}^{\circ}\right]$ sence de dieu vivant, duquel portez le nom qui vous a donné la puissance du glaive pour en user a son honneur, deffendans les innocens, punissans tous malfaicteurs, soyez trouvez fideles et 
veritables, consentans a tout bien, resistans au mal de vostre puissance, pour sa bonne volunté, car par luy estes vous a ce commis, et luy seul vous peult exalter ou deprimer en la vie presente et future, et de ce soyez acertenez: si vous tachez l'honnerer, il vous honnorera; si vous l'exaltez, il vous exaltera. Par sa sagesse, les roys regnent et les seigneurs dominent et ordonnent sainctes ordonnances.

36. The same passage from Proverbs is quoted, e.g., by Christopher St German, Dyaloge in Englysshe bytwyxt a doctoure of dyvynyte and a student in the lawes of Englande (London: Robert Wyer, 1530?), p. 12 in Montgomery, ed.: "By me kings reign, and Makers of Law discern the truth."

37. See the OED.

38. Boke of Marchauntes, Aiii v ${ }^{\circ}$

39. Boke of Marchauntes, Aiii $\mathrm{r}^{\circ}$ - Aiii $\mathrm{v}^{\circ}$. Compare Livre des marchans (1533), Aii $\mathrm{r}^{\circ}$ Aii $v^{\circ}$ :

Et par ainsi personnages laborieux, diligens, industrieux sont requis pour l'entretenement de la chose publicque, lesquelz sans finesse, sans fraude ou cautelle, ayent a distribuer, [Aii $\mathrm{v}^{\circ}$ ] commuer, changer, conserver et transporter plusieurs sortes de marchandises d'ung lieu en autre selon l'exigence du temps et necessité du peuple. Ausquelz loyaulx marchans est bien licite, comme a bons et fideles serviteurs de la chose commune.

40. Boke of Marchauntes, Aiii $\mathrm{v}^{\circ}$ - Aiv $\mathrm{r}^{\circ}$. See Livre des marchans, Aii $\mathrm{v}^{\circ}$-Aiii $\mathrm{r}^{\circ}$ :

Cest estat dont je parle, autant [Aiii $\mathrm{r}^{\circ}$ ] que en la chose temporelle et civile est honnorable, autant est il en la chose spirituelle et divine, mauldict et detestable. Et toutesfoys dieu a permis en sa fureur que, au lieu de bons pasteurs et veritables ministres de sa saincte parolle, soyent en l'eglise survenuz, je ne dis pas seulement gros marchans, mais furieux larrons et insatibles loups ravissants.

41. Calvin, Institute of the Christian Religion (1559) III.19.15

42. For a discussion of the appeal to the lex divinitatis by Boniface see David Luscombe, "The 'Lex Divinitatis' in the Bull 'Unam Sanctam' of Pope Boniface VIII," in C.N.L. Brooke, et al., eds., Church and Government in the Middle Ages (New York: Cambridge University Press, 1976), pp. 205-21. See also Wayne J. Hankey, “'Dionysius dixit, Lex divinitatis est ultima per media reducere': Aquinas, hierocracy and the 'augustinisme politique'," in Ilario Tolomio, ed., Tommaso D'Aquino: proposte nuove di letture. Festscrift Antonio Tognolo, Medioevo. Rivista di Storia della Filosofia Medievale, 18 (Padova: Editrice Antenore, 1992), pp. 119-50.

43. Corpus Iuris Canonici, ed. Emil Friedberg (Leipzig: B. Tauchnitz, 1879; reprinted Graz: Akademische Druk-u. Verlagsanstalt, 1955; 1959), vol. 2, col. 1245-6:

One sword ought to be subordinated to the other, and temporal authority subjected to spiritual power. For, since the Apostle said: 'There is no power except from God and those that are, are ordained of God' [Rom 13: 1-2], they would not be ordained if one sword were not subordinated to the other and if the inferior one, as it were, were not led upwards by the other. For according to the Blessed Dionysius, it is the law of divinity that the lowest things are led to the highest by intermediaries. Then, according to the order of the universe, all things are not led back equally and immediately, but the lowest by the intermediary, and the inferior by the superior...Therefore if the 
terrestrial power err, it will be judged by the spiritual power; but if a minor spiritual power err, it will be judged by a superior spiritual power; but if the highest power of all err, it can be judged only by God, and not by man... This authority is not human but rather divine, granted to Peter by a divine word and reaffirmed to him and his successors... Therefore whoever resists this power thus ordained by God, resists the ordinance of God [Rom 13: 2], unless he invent like Manicheus two beginnings...

See Giles of Rome, De ecclesiastica potestate ed. Arthur P. Monahan (Lewiston, 1990) I.4, pp.17-20 and Monahan's introduction, p. xxvii. For Thomas Aquinas's classical formulation of the lex divinitatis see Summa Theologica IIa, IIae Q. 172, art. 2.

44. Boke of Marchauntes, Aii $\mathrm{v}^{\circ}$

45. Boke of Marchauntes, Aiii $\mathrm{r}^{\circ}$

46. Boke of Marchauntes, Biv v ${ }^{\circ}$

47. The workes of Geffray Chaucer newly printed, with dyuers workes whiche were neuer in print before: as in the table more playnly dothe appere, ed. William Thynne (London: Thomas Godfray, cum priuilegio, 1532). See Canterbury Tales, ed. A.C. Cawley (London: Dent, 1975), pp. 494-518. The canon's yeoman's reference to his master's "slidynge science" (1.732) and "crafty science" (1.1253) has an echo in the "sleyghtnesse" [habilité] of Marcourt's merchants; both the 'Canon's Yeoman's Tale' and Marcourt's satire convey a travesty of transubstantiation. Compare Boke of Marchauntes, Avi.

48. Canterbury Tales, ed. Cawley, 11. 424-6; see pp. 343-60.

49. Lorenzo Valla, De falso credita et ementita Constantini donatione libellus (Strasbourg: Gruninger, 1506); translated by William Marshall and published by Thomas Godfray under the title $A$ treatyse of the donation or gyfte and endowme[n] tof possessyons, gyuen and graunted vnto Syluester pope of Rhome, by Constantyne emperour of Rome (London: Thomas Godfray, 1534).

50. Marsilius of Padua, The defence of peace: lately translated out of laten in to englysshe, with the kynges moste gracyous priuilege (London: Robert Wyer, 1535). Although completed in 1324 and circulated in manuscript, the original Latin text was not printed until 1522 in the Basle edition by Beatus Bildius. Opus insigne cui titulum fecit autor [Marsilius] Defensorem pacis, (Basle, 1522).

51. Shelley C. Lockwood, "Marsilius of Padua and the case for the royal ecclesiastical supremacy," Transactions of the Royal Historical Society 6.1 (1990), pp. 89-119. See Rex, "Crisis of Obedience," p. 882.

52. In a letter to Cromwell, Marshall indicates that he is relying on Cromwell's promise of a subsidy of 20 pounds for the printing of his translation of Marsilius' work. See Letters and Papers of Henry VIII, 7:423.

53. According to Augustine, the two cities - the civitas Dei and the civitas terrena - are constituted by two modes of love, viz. amor Dei and libido dominandi. See de civitate Dei, XIV.1. For Augustine it is characteristic of the latter to confuse the finite and temporal good with the infinite and eternal good, and this is the nub of Marcourt's satire.

54. Marsilius, Defender of the Peace:

Christ Himself did not come into the world to rule men, or to judge them by civil judgment, nor to govern in a temporal sense, but rather to subject Himself to the state and condition of this world; that indeed from such judgment and rule He wished to 
exclude and did exclude Himself and His apostles and disciples, and that He excluded their successors, the bishops and presbyters, by His example, and word and counsel and command from all governing and worldly, that is, coercive rule. I will also show that the apostles were true imitators of Christ in this, and that they taught their successors to be so. I will further demonstrate that Christ and His apostles desired to be subject and were subject continually to the coercive jurisdiction of the princes of the world in reality and in person, and that they taught and commanded all others to whom they gave the law of truth by word or letter, to do the same thing, under penalty of eternal condemnation.

See Paul Halsall, Medieval Source Book, http://www.fordham.edu/halsall/source/marsiglio4.html, accessed 26 March 2005.

55. Martin Bucer, Das Einigerlei Bild bei den Gotglaubigen an Orten da Sie Verehrt, Nit Mogen Geduldet Werden (Strasbourg: Johann Knobloch, 1530), quoting from Opera Omnia, Deutsche Schriften, Vol. IV 'Zur auswärtigen Wirksamkeit 1528-1533,' (Güteresloh: Güteresloher Verlagshaus, 1960), p. 167. William Marshall's translation, published by Godfray, is titled A treatise declaryng [and] shewing dyuers causes take[n]out of the holy scriptur[es], of the sente[n]ces of holy faders, [and] of the decrees of deuout emperours, that pyctures [and] other ymages which were wont to be worshypped, ar i[n] no wise to be suffred in the temples or churches of Christen men (London: Thomas Godfray, 1535?). Marshall's translation is not made directly from the German of Das Einigerlei Bild, but rather from a Latin translation of Bucer's text by Jacobus Bedrotus, Non esse ferendas in Templis Christianorum Imagines et Statuas (Strasbourg: Johann Knobloch, 1530). I am indebted to John McDermid for this observation.

56. Jacques Lefèvre d'Étaples, "Preface to the Commentary of the Four Gospels," Eugene F. Rice, ed., The Prefatory Epistles of Jacques Lefèvre d'Étaples (New York: Columbia University Press, 1972), p. 436.

57. Boke of Marchauntes, Aviii $\mathrm{v}^{\circ}$ - $\mathrm{Bi} \mathrm{r}^{\circ}$. Marcourt perhaps refers to the late-medieval spiritual practice of gazing upon the host or on sacred relics, as was the practice at the shrine of Thomas Becket in Canterbury Cathedral - a spiritual benefit to be "purchased" by the worshipper.

58. A treatise concernynge the diuision betwene the spiritualtie and temporaltie (London: Thomas Berthelet, 1532?); Salem and Bizance (London: Thomas Berthelet, 1533).

59. An answere to a letter (London: Thomas Godfray cum priuilegio, 1535); see also $A$ treatyse concernige the powre of the clergye and the lawes of the realme (London: Thomas Godfray, 1535?).

60. St German, Answer to a Letter, Giv r ${ }^{\circ}, \mathrm{Gv} \mathrm{r}^{\circ}$. Compare Powre of the clergye, Diiii.

61. Boke of Marchauntes, Cii $\mathrm{v}^{\circ}$ - Ciii $\mathrm{r}^{\circ}$. On the importance of the invocation of the Old Testament model of kingship in the campaign of the 1530s in support of Henry's claim to headship of the Church of England, see Rex, Henry VIII and the English Reformation.

62. Ethan Shagan, "Clement Armstrong and the godly commonwealth: radical religion in early Tudor England," The Beginnings of English Protestantism (Cambridge: Cambridge University Press, 2002), p. 61. Shagan argues that

it is a commonplace of scholarly analyses of the 'radical Reformation' that radical theology required churches to be organised 'on the principle of voluntary association' [quoting George Williams, The Radical Reformation, xxviii] and that radicals 
'disdained a settled relationship with secular society.'... yet in Armstrong's case we have what seems to be an authoritarian and hyper-institutionalist concoction mixed from many of the same elements found in the Anabaptist theological brew. In the English Reformation 'radical' and 'magisterial' cannot function as simple antonyms... In England of the early 1530s... the hopes of a small evangelical minority lay in the policies of a mercurial king who had begun making dark threats against the pope and the clergy. (See p. 78).

63. Public Record Office, State Papers, Theological Tracts 6/11, $199 \mathrm{v}^{\circ}$. Cited in Ethan Shagan, p. 74.

64. See Berthoud, p. 141: “Godfray, on l'a vu, n'a dissimulé ni son nom, ni son adresse, mais n'a pas renoncé totalement pour autant aux indications fictives de Pierre de Vingle... D'autre part, 'l'Imprimé à Corinthe' est devenu 'Written at Corinthe, by your frende and lover (out of frenche) Thorny, wyld, wedy, harletry.' Le traducteur ne s'est malheureusement pas trahi davantage par ces mots énigmatiques."

65. Livre des Marchans (1533), $\mathrm{Ci}^{\circ}$ [my italics]. I am grateful to Isabelle Crevier-Denommé for drawing this critical discrepancy in the translation to my attention.

66. Boke of Marchauntes, Ciii $\mathrm{r}^{\circ}$

67. In addition to the volumes published by Godfray already mentioned, Marshall's translations included the following: Girolamo Savonarola, An exposition vpon the li Psalme, called Miserere mei deus (London: Thomas Godfray, cum privilegio regali, 1535?); also The forme and maner of subue[n] tion or helping for pore people, deuysed and practysed $i[n]$ the cytie of Hypres in Flaunders, whiche forme is auctorised by the Emperour, [and] approued by the facultie of diuinitie in Paris (London: Thomas Godfray, cum privilegio regali, 1535). James McConica notes that "interest in Savonarola, a marked concern of the Erasmian community everywhere, was early a property of the English group-Savonarola's meditation on the 'Miserere mei, Deus' was one of the most poignant and widely circulated documents of the pre-reform period." McConica, p. 195.

68. See Robert Peters's introductory note to the Scolar press facsimile edition of The sum of the Holy Scripture and A supplication for the beggars 1529 (Menston: Scolar Press, 1973).

69. An epistle of sai[n]t Bernarde, called the golden epistle, whiche he se[n]t to a yo[n]g religyous man whom he moche loued. And after the sayd epistle, foloweth four reuelations of Saint Birget (London: Thomas Godfray, 1535). Translation of the "golden epistle" or "de perfectione vitae" is attributed to Christopher St German by John Bale, Index Britanniae scriptorium, compiled (1548-1554) and to Richard Whitford of Syon House by McConica, p. 116. See Edmund Colledge, "Fifteenth- and Sixteenth-century versions of 'The Golden Epistle of Saint Bernard'," Medieval Studies 37 (1975), pp. 122-9. The "golden epistle" is now usually attributed to Bernard's friend William of St Thierry.

70. Giles du Wes, An introductorie for to lerne to rede, to pronounce, and to speke Frenche trewly, 2 vols. (London: Thomas Godfray, 1534), repr. 1 vol. (Genève: Slatkine reprints, 1972). Christian Schmitt, "La grammaire de Giles du Wes, étude lexicale," Revue de linguistique romane 43(1979), pp. 1-45. Originally from Flanders, Du Wes was 'keeper of the Library at Richmonte.'

71. John Foxe, Actes and monuments of these latter and perillous dayes, touching matters of the Church, wherein ar comprehended and described the great persecutions [and] hor- 
rible troubles, that haue bene wrought and practised by the Romishe prelates, speciallye in this realme of England and Scotlande... (London: John Day, cum privilegio Regice Maiestatis, 1563).

72. The catalogue of prohibited books is recorded only in the first edition of Actes and Monuments (1563), pp. 573-4. The Royal Proclamation, issued on 8 July 1546, is included in the Bonner Register, followed by Edmund Bonner's own certificate to the Privy Council confirming execution of the order together with a list of prohibited books, Guildhall MS 9531/12, pt1, folio $91 \mathrm{r}^{\circ}$ :

The king's most excellent majesty - understanding how, under pretence of expounding and declaring the truth of God's Scripture, divers lewd and evil-disposed persons have taken upon them to utter and sow abroad, by books imprinted in the English tongue, sundry pernicious and detestable errors and heresies, not only contrary to the laws of this realm, but also repugnant to the true sense of God's law and his word... His majesty straitly chargeth and commandeth, that no person or persons, of what estate, degree, or condition soever he or they be, from the day of this proclamation, presume to bring any manner of English book, concerning any manner of Christian religion, printed in the parts beyond the seas, into this realm...

See Tudor Royal Proclamations, ed. P. L. Hughes and J. F. Larkin, 3 vols. (New Haven: Yale University Press, 1964) vol 1, pp. 373-6. On the Paris index see Benedict and Reinburg, p. 139.

73. See Edmund Bonner's Certificatorium factum dominis de privato consilio regio super concrematione quorundam librorum prohibitorum, Guildhall MS 9531/12, folio $91 \mathrm{v}$; repr. Actes and Monuments (London: Adam and Company, 1873), appendix to vol. V, no. xviii.

74. The summe of the holye scripture: and ordinarye of the Christen teachyng, the true Christen faithe, by the whiche we be all iustified (Antwerp?: s.n., 1529). As was The Boke of Marchauntes, Turner's translation of The summe was printed once again shortly after the accession of Edward VI. Isabelle Crevier-Denommé has shown that this text had a relatively complex publication history having been translated into English and Italian as well as French. See her as yet unpublished paper "Les changements doctrinaux dans les versions de la Summe de l'escripture saincte (1529-1539)," presented at the colloquium "Les impressions réformées de Pierre de Vingle" at the UK Society for Renaissance Studies, Cambridge University, April 2005.

75. De Summa der Godliker Scrifturen (Leyden, 1523), ed. Johannes Trapman (Leiden: Elve/ Labor Vincit, 1978). Published anonymously in 1523 the Summa was a free translation by Bomelius of his Latin work Oeconomica Christiana which was not published until 1527.

76. Simon Fish, A supplication of the poore commons. Wherunto is added the Supplicacyon for the beggers (London: John Day and William Seres?, 1546). Sir Thomas More engaged Fish in defense of the doctrine of Purgatory as he did John Frith. See The supplycacyon of soulys made by syr Thomas More knight... Agaynst the supplycacyon of beggars (London: William Rastell, 1529).

77. See "Les changements doctrinaux dans les versions de la Summe de l'escripture saincte (1529-1539)," colloquium “Les impressions réformées de Pierre de Vingle,” April 2005.

78. McConica, pp. 10, 11. 
60/ Renaissance and Reformation / Renaissance et Réforme

79. For an illuminating analysis of religious reform in the years immediately preceding the accession of Edward VI, see Alec Ryrie, "The Strange Death of Lutheran England," Journal of Ecclesiastical History 53.1 (Jan. 2002), p. 83-92. As Ryrie sums it up, there is a significant division of opinion in the interpretation of this period. Richard Rex sees it as an almost fully-fledged Counter-Reformation while Eamon Duffy regards the Reforming party as biding their time in anticipation of the succession. [Nothing succeeds like succession?] See Rex, Henry VIII, p. 144 and Eamon Duffy, The Stripping of the Altars (New Haven and London: Yale University Press, 1992), pp. 424-47. On this historiographical divergence, see Ryrie, p. 83.

80. Benedict and Reinburg, p. 139.

81. Philip Benedict, "The Wars of Religion, 1562-1598," in Mark Holt, ed., Renaissance and Reformation France, 1500-1648 (Oxford: Oxford University Press, 2002), p. 150. 